\title{
Taxonomic differentiation of Ursus arctos (Carnivora, Ursidae) from south Okhotsk Sea islands on the basis of morphometrical analysis of skull and teeth
}

\author{
Gennady F. Baryshnikov, Tsutomu Mano \& Ryuichi Masuda
}

\begin{abstract}
The comparative analysis of the skull and teeth of the brown bear from Hokkaido was carried out for three geographical groups previously established on the basis of mitochondrial DNA analysis (Matsuhashiet al., 1999). As a result of morphometrical testing, the isolation of the bears from Eastern group, which possess smallest cheek teeth, has been ascertained. While morphometrical characters of males belonging to Central group and Southern group was similar, females of these groups demonstrated reliable differences. In spite of the differentiation of Eastern group approaches to the subspecific level, all the brown bears from Hokkaido and southern Kuril Islands are referred to the subspecies U. arctos ferox Temminck, 1844.
\end{abstract}

KEY-WORDS: Ursus arctos, skull, teeth, sexual dimorphism, geographical variability, Japan.

Gennady F. Baryshnikov [G_Baryshnikov@mail.ru], Zoological Institute, Russian Academy of Sciences, Universitetskaya nab. 1, Saint Petersburg 199034, Russia; Tsutomu Mano [mano@hokkaido-ies.go.jp], Hokkaido Institute of Environmental Sciences, Kita-19, Nishi-12, Kita-ku, Sapporo 060-0819, Japan; Ryuichi Masuda [masudary@ees.hokudai.ac.jp], Center for Advanced Science and Technology, Hokkaido University, Sapporo 0600810, Japan.

\section{Таксономическая дифференциация бурого медведя Ursus arctos (Carnivora, Ursidae) с островов южной части Охотского моря на основе морфометрического анализа черепа и зубов}

\author{
Геннадий Барышников, Цутому Мано, Риуичи Масуда
}

\begin{abstract}
РЕЗЮМЕ. Проведен сравнительный анализ черепа и щечных зубов бурого медведя с Хоккайдо из 3 географических групп, установленных ранее по данным митохондриальной ДНК (Matsuhashi et al., 1999). В результате морфометрического тестирования подтверждено обособление медведей восточной группы, щечные зубы которых самые мелкие. Самцы центральной и южной групп оказались морфометрически сходными, однако самки из этих групп показали достоверные различия. Хотя уровень обособления восточной группы приближается к подвидовому, все бурые медведи Хоккайдо и южных Курил отнесены к подвиду U. arctos ferox Temminck, 1844.
\end{abstract}

КЛЮЧЕВЫЕ СЛОВА:Ursus arctos, череп, зубы, половой диморфизм, географическая изменчивость, Япония.

\section{Introduction}

The brown bear (Ursus arctos L., 1758) is widely distributed through the northern Eurasia, including islands of the southern part of Okhotsk Sea: Shantarskie Islands, Sakhalin, Hokkaido, and southern Kuril Islands (Kunashir, Iturup). In the Late Pleistocene, this species also inhabited Honshu (Kamei 1981).

Temminck (1842: 29) was the first who gave the scientific name for the brown bear from Japan: U. ferox. Lydekker (1897) and his followers (Pocock, 1932: 804, Ellermann \& Morrison-Scott, 1951: 238) mistakenly treated this name to be preoccupied by $U$. ferox Rafinesque (1817: 437) and U. ferox "Lewis \& Clark" in Desmarest (1820: 164). However, both latter names, which were used for the brown bear from North Amer- ica, are nomina nudi; therefore, there are no nomenclatural grounds to refuse Temminck's name.

Middendorff (1851: 80) described the brown bear from the Greater Shantar Island as U. arctos var. beringiana, with its distribution range comprising the eastern coast of Siberia and Japan. Ognev (1931: 94) has designated the skull of the adult male (ZIN 1226) as a lectotype for this taxon, erroneously pointing out the Smaller Shantar Island to be a type locality (see Abramov \& Baryshnikov, 1990: 8).

Pucheran (1855: 392), without any diagnose, named the brown bear from Kamchatka as U. piscator on the basis of the data by I. Geoffroy Saint-Hillaire, published in his report on the trip by the frigate "La Vénus" (holotype: mounted skin 2001-357 in Muséum National d'Histoire Naturelle, Paris). 
A new species, U. lasiotus (holotype NHM 93.9.10.1), has been established by Gray (1867: 301) for the living bear brought from the inner part of Northern China and kept during a long period of time at the London Zoo (see Pocock, 1932: 799). This name has been repeatedly used for insular brown bears from southern part of the Okhotsk Sea.

Lydekker (1897: 422, fig. 3, 4) described the subspecies $U$. arctos yesoensis on the basis of three brown bear skulls from Hokkaido. He gave a drawing of the skull of a young adult male (NHM 86.11.18.2), which we designate as the lectotype. Another skull, belonging to adult male (NHM 96.4.27.1), is correspondingly the paralectotype. In spite of the name $U$. a. yesoensis is widely used in recent publications, it seems to be a junior synonym of $U$. a. ferox, as well as U. melanarctos (Heude, 1898: 17) proposed for the brown bear from Hakodae in Hokkaido.

The recent authors diverged in opinions on the taxonomic position of the brown bear from islands of the southern part of the Okhotsk Sea. Ognev (1931: 104), accepting several species for the brown bear in Eurasia, suggested similarity of the Sakhalin specimens with bears from Hokkaido, and assigned Sakhalin bears to a new unnamed subspecies of U. yesoensis. Pocock(1932) referred the brown bears from Hokkaido and southern Kuril Islands to the mainland subspecies, U. a. lasiotus, and used the name $U$. a. beringianus for brown bears from the western and northern coast of the Okhotsk Sea and Kamchatka. This point of view has been accepted by Ellermann \& Morrison-Scott (1951) and Novikov (1956).

Stroganov (1962) regarded all the brown bears living in the Okhotsk Sea region as the subspecies $U$. $a$. beringianus. Heptner (Heptner et al., 1967) recognized two subspecies for this region: U. a. piscator (Kamchatka and Okhotsk Sea coast as far as Stanovoi Range and Shantarskie Islands southwards) and U. a. lasiotus (mainland areas to the south of Stanovoi Range, Sakhalin, southern Kuril Islands and Hokkaido), erroneously ascribing the name beringianus to bears from the northwestern part of North America. Corbet (1978) assigned all the brown bears of Northern Eurasia, including Hokkaido, to the nominotypical subspecies, U. a. arctos.

Later, it was revealed that the bears from the western and northern coast of the Okhotsk Sea differ from $U$. $a$. beringianus (=lasiotus), with their attribution to the subspecies U. a. jeniseensis Ognev, 1924 described from the southern part of Eastern Siberia (Cherniavsky, 1986; Cherniavsky \& Kretchmar, 2001). At the same time, $U$. a. jeniseensis is a junior synonym of $U$. $a$. collaris Geoffroy Saint-Hillaire et F. Cuvier, 1824.

Baryshnikov (Aristov \& Baryshnikov, 2001) included brown bears of the northeastern Asia to the subspecies $U$. a. arctos, considering U. a. piscator (Kamchatka, northern Kuril Islands) and U. a. beringianus (Amur River basin, Shantarskie Islands, Sakhalin, Hokkaido, and southern Kuril Islands) to be the separate subspecies.

Thus, there is no conventional view on the taxonomic status of the brown bears inhabiting Okhotsk Sea region.

Cherniavsky (1984), studying the geographical variability of $U$. arctos, revealed the tendency in the size decrease for bears from south (Amur River basin) and east (Kamchatka) toward northern-west (Yakutia). Besides, populations from Kamchatka and Amur River basin diverge in the width of skull zygomatic arch.

The study of the $U$. arctos from Hokkaido has also revealed the geographical heterogeneity of the local brown bears. The clinal increase of the cranium from south to northeast has been demonstrated (Yoneda \& Abe, 1976). Three morphometrically differend populations were also established (Ohdachiet al., 1992). Later, the study of mitochondrial DNA (mtDNA) revealed the presence of three bear genetic lineages (clusters A, B and C) separately located in various parts of the island and different timing of migration of each cluster to Hokkaido from the mainland (Matsuhashi et al., 1999). However, associations between morphometrical and genetic groups remain unclear.

The focus of the present study is a comparative craniometrical analysis of 3 genetic groups of brown bears in Hokkaido and reconsideration of the subspecific status for $U$. arctos from islands in the south parts of Okhotsk Sea.

\section{Material and methods}

The skulls belonging to 54 males and 36 females of $U$. arctos from Hokkaido, southern Kuril Islands, Sakhalin and Shantarskie Islands have been examined. Measurements were taken only from adults: males elder than seven years and females elder than five years. The male skulls of the brown bear from Eastern Europe, Siberia, Kamchatka and Amur River basin were used as comparative material. The collections of Hokkaido Institute of Environmental Sciences in Sapporo (HIES), Field Sciences Center of Northern Biosphere, Hokkaido University in Tomakomai (FSCVB), National Sciences Museum in Tokyo (NSMT), Zoological Institute, Russian Academy of Sciences in St. Petersburg (ZIN), Zoological Museum, Moscow State University (ZMMU), and Natural History Museum in London (NHM) have been involved in the study.

The skulls of bears from Hokkaido were grouped into three geographical units with their limits coincide with those for three mtDNA clusters: Central group, corresponding to Cluster A, Eastern group (Cluster B) and Southern group (Cluster C) (Fig. 1). In addition, the bears inhabiting Nemuro Peninsula were conditionally referred to the Central group, whereas bears from islands of Kunashir and Iturup were provisionally placed into Eastern group. The both samples were not genetically studied.

The bear skull dimensions are shown in the Fig. 2. The canine width was measured at the level of the enamel lower margin. The bear check teeth were measured using the earlier published scheme, which includes 30 measurements for each specimen (Baryshnikov, 1998; Baryshnikov \& David, 2000). The dimensions were taken with the dial callipers with accuracy up to $0.1 \mathrm{~mm}$. The data were processed by Discriminant Analysis and Cluster Analysis from STATISTIKA 6.0 


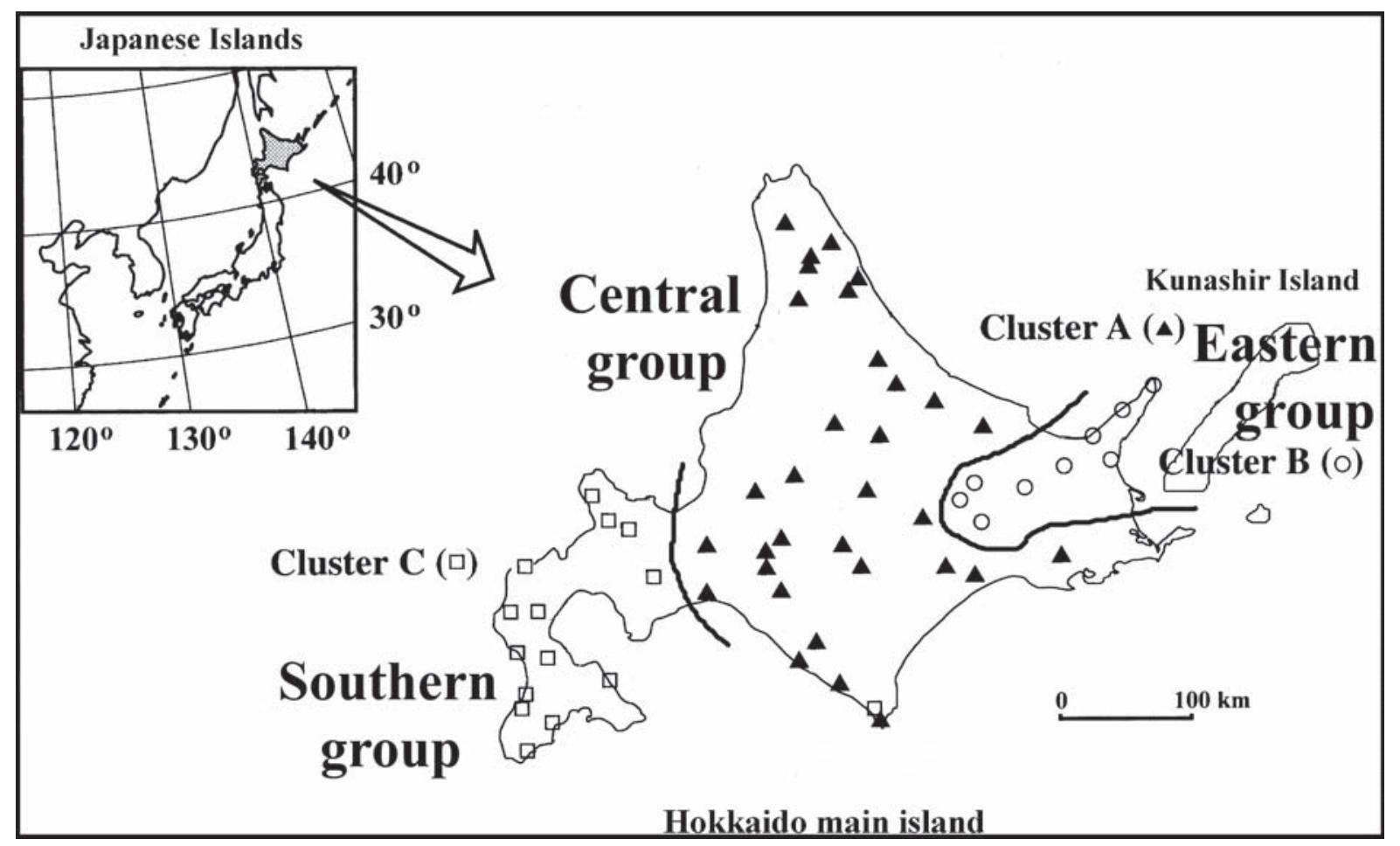

Figure 1. Distribution of geographical groups of Ursus arctos ferox in Hokkaido and southern Kuril Islands with regard of distribution of brown bear genetic clusters A, B and C (Matsuhashi et al., 1999).

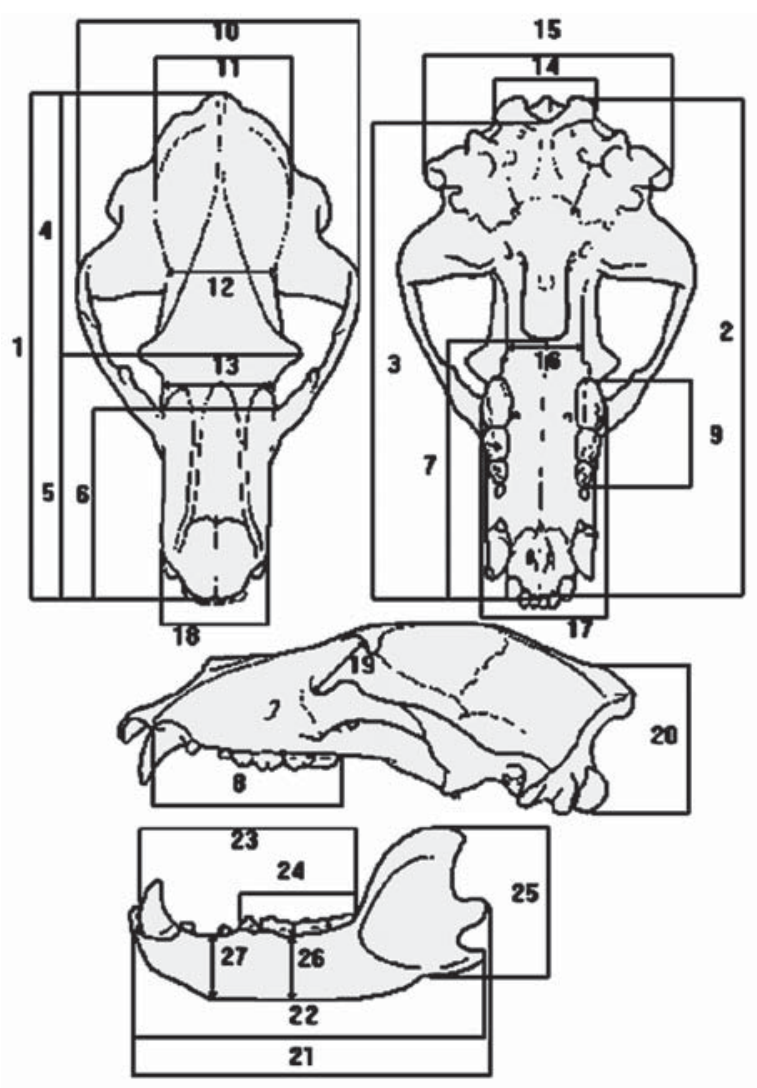

Figure 2. Scheme of skull measurements of Ursus arctos.
('99 edition). In Discriminant Analysis, we used the forward stepwise method.

\section{Results}

Males of the brown bear are larger than females, therefore the sexual dimorphism is pronounced in the size of their skulls. The measurements of skulls in the males and females of U. a. ferox are shown in the Tab. 1. Among cranial measurements, the most valuable for segregation of sexes in the brown bear were height of the vertical ramus of mandible, total length of skull and total length of mandible. In the condylobasal length of skull, the males of $U$. a. ferox are approximately $18 \%$ larger than females.

The frequency distribution of tooth dimensions revealed that males of $U$. arctos reliably differ from females $(\mathrm{P}<0.000001)$ in the canine width (Fig. 3$)$, as well as in the upper (P4) and lower (m1) carnassial length (Fig. 4). These data ascertain the presence of the sexual dimorphism in bears not only in the canine size (Kurtén, 1955), but also in the dimensions of cheek teeth, as it has been stated earlier (Baryshnikov et al., 2003). In the upper canine width, the males of U. a. ferox are approximately $27 \%$ larger than females.

The development of sexual dimorphism varies in different geographical groups of the brown bear from Hokkaido. In Central group, males and females are well distanced by the width of upper and lower canines. However both sexes of Southern group overlap in the canine size (Fig. 5). 
Table 1. Skull sizes in Ursus arctos ferox.

\begin{tabular}{|c|c|c|c|c|c|c|c|c|c|c|}
\hline \multirow{2}{*}{$\begin{array}{l}\text { Measurements, } \\
\mathrm{mm}\end{array}$} & \multicolumn{5}{|c|}{ Males } & \multicolumn{5}{|c|}{ Females } \\
\hline & $\mathrm{n}$ & $\min$ & $\max$ & M & SD & $\mathrm{n}$ & $\min$ & $\max$ & M & SD \\
\hline 1 & 42 & 325.0 & 405.0 & 365.27 & 17.98 & 28 & 283.4 & 326.4 & 302.86 & 12.69 \\
\hline 2 & 41 & 310.1 & 382.0 & 339.16 & 16.40 & 26 & 264.6 & 306.0 & 286.70 & 11.32 \\
\hline 3 & 38 & 291.0 & 362.0 & 317.77 & 16.16 & 24 & 249.2 & 289.0 & 268.93 & 10.55 \\
\hline 4 & 42 & 172.8 & 236.3 & 205.98 & 12.81 & 27 & 142.5 & 182.5 & 165.43 & 9.16 \\
\hline 5 & 49 & 162.0 & 220.0 & 186.10 & 11.73 & 30 & 141.7 & 173.2 & 157.85 & 8.78 \\
\hline 6 & 48 & 122.2 & 158.8 & 139.03 & 8.59 & 31 & 102.7 & 131.9 & 119.14 & 7.50 \\
\hline 7 & 46 & 154.6 & 208.8 & 180.02 & 10.61 & 28 & 139.8 & 166.1 & 153.92 & 7.37 \\
\hline 8 & 49 & 112.4 & 138.9 & 127.26 & 6.30 & 31 & 106.2 & 122.5 & 114.59 & 4.59 \\
\hline 9 & 49 & 66.8 & 83.3 & 73.73 & 3.69 & 31 & 62.3 & 73.1 & 68.27 & 2.66 \\
\hline 10 & 46 & 169.8 & 256.6 & 211.01 & 20.91 & 30 & 157.9 & 190.4 & 175.98 & 7.11 \\
\hline 11 & 42 & 96.1 & 110.3 & 102.01 & 3.07 & 27 & 90.4 & 100.4 & 95.35 & 2.98 \\
\hline 12 & 43 & 66.3 & 85.4 & 75.58 & 3.94 & 28 & 64.5 & 81.7 & 70.94 & 3.84 \\
\hline 13 & 48 & 59.7 & 94.6 & 78.36 & 7.56 & 31 & 58.1 & 75.4 & 66.40 & 4.27 \\
\hline 14 & 38 & 64.4 & 78.7 & 71.89 & 3.10 & 23 & 56.8 & 68.8 & 62.73 & 2.46 \\
\hline 15 & 42 & 140.7 & 195.0 & 170.03 & 15.02 & 27 & 122.9 & 147.7 & 131.40 & 5.89 \\
\hline 16 & 44 & 40.3 & 55.3 & 47.27 & 3.19 & 28 & 37.8 & 48.1 & 42.94 & 2.41 \\
\hline 17 & 49 & 74.5 & 95.5 & 84.94 & 4.37 & 31 & 70.4 & 83.7 & 77.19 & 3.08 \\
\hline 18 & 49 & 67.6 & 91.6 & 79.13 & 5.48 & 31 & 59.9 & 71.8 & 65.79 & 3.16 \\
\hline 19 & 49 & 40.3 & 57.1 & 48.78 & 3.85 & 30 & 37.5 & 46.6 & 42.34 & 2.22 \\
\hline 20 & 38 & 87.3 & 124.4 & 103.36 & 7.34 & 24 & 73.5 & 87.6 & 80.14 & 3.43 \\
\hline 21 & 48 & 209.5 & 268.8 & 238.74 & 12.72 & 31 & 193.0 & 220.6 & 206.17 & 8.19 \\
\hline 22 & 45 & 209.7 & 276.5 & 240.48 & 12.44 & 31 & 188.2 & 221.4 & 207.43 & 8.12 \\
\hline 23 & 49 & 128.3 & 159.8 & 145.54 & 6.81 & 31 & 121.1 & 137.0 & 129.09 & 4.56 \\
\hline 24 & 49 & 67.7 & 98.5 & 81.67 & 4.43 & 31 & 69.8 & 81.9 & 76.73 & 3.30 \\
\hline 25 & 48 & 89.8 & 124.9 & 109.11 & 7.33 & 31 & 81.8 & 99.7 & 87.67 & 4.24 \\
\hline 26 & 46 & 37.7 & 62.0 & 45.45 & 4.48 & 31 & 30.1 & 45.1 & 37.16 & 2.94 \\
\hline 27 & 49 & 37.8 & 53.4 & 43.60 & 3.27 & 31 & 28.5 & 42.6 & 36.18 & 3.15 \\
\hline
\end{tabular}

Abbreviations: $\mathrm{n}$ - number of specimens, min — minimum easurement, max — maximum measurement, $\mathrm{M}$ - mean, SD - standard deviation.

The comparative craniometrical study has also revealed the differences between brown bears belonging to different geographical groups in the size as well as proportions of the skull. This study ascertained the somewhat smaller size of the brown bears belonging to Southern group, which has already pointed out by the preceding investigators (Tab. 2). Thus, the mean of the skull condylobasal length in the males from Southern group (334.2 mm, $\mathrm{n}=18$ ) was markedly smaller than in males from Central group $(342.8 \mathrm{~mm}, \mathrm{n}=11)$ and Eastern group (342.6 mm, $\mathrm{n}=9$ ). The two latter groups are similar in this dimension.

The multiple discriminant function analysis fulfilled on the basis of 27 skull measurements has indicated a distinct isolation of males belonging to Eastern group (Fig. 6), statistically well distinguishing this group from two other groups $(\mathrm{P}<0.0004)$. The brown bears from
Eastern group seem to have broader skulls, since they are isolated by the first canonical variate Root 1 , which discriminates the greatest neurocranium breadth, greatest mastoid breadth, and least breadth between the orbits ( $84 \%$ of skull variation). The Southern and Central male groups are quite similar.

Lectotype of $U$. a. yesoensis (NHM 86.11.18.2) is placed by the discriminant analysis into Eastern group, whereas the paralectotype (NHM 96.4.27.1) is sorted by the analysis into Southern group.

The result based on the analysis of females is different: the reliable distinction has revealed between Southern and Central groups $(\mathrm{P}<0.003)$ as well as that between Central and Eastern groups $(\mathrm{P}<0.09)$. Brown bears from Southern and Central female groups were divided by the first canonical variate Root 1 , which discriminates skull height, condylobasal length, least 

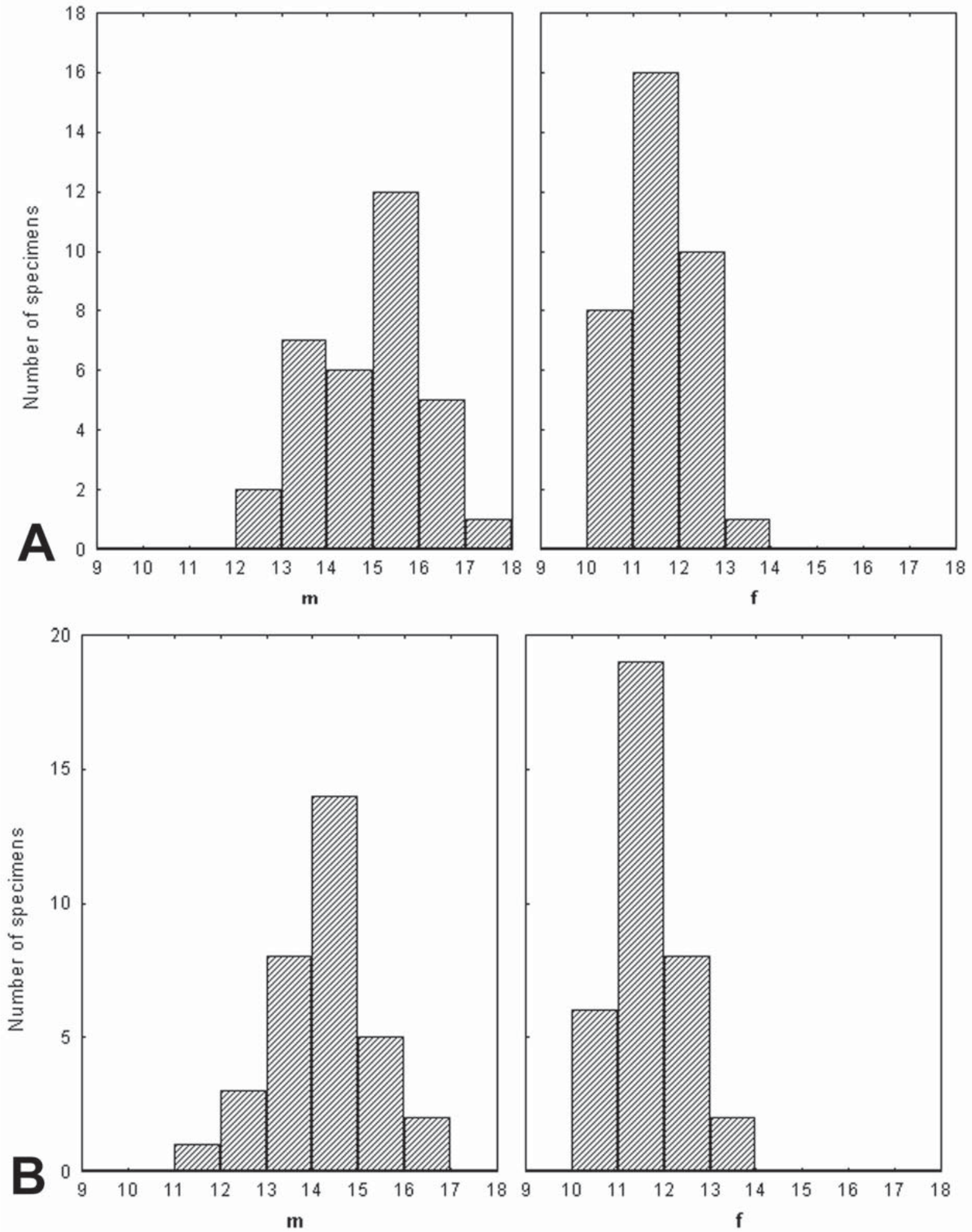

Figure 3. Frequency distribution of upper (A) and lower (B) canine width (in $\mathrm{mm}$ ) in males (m) and females (f) of $U$. $\operatorname{arctos}$ ferox. 

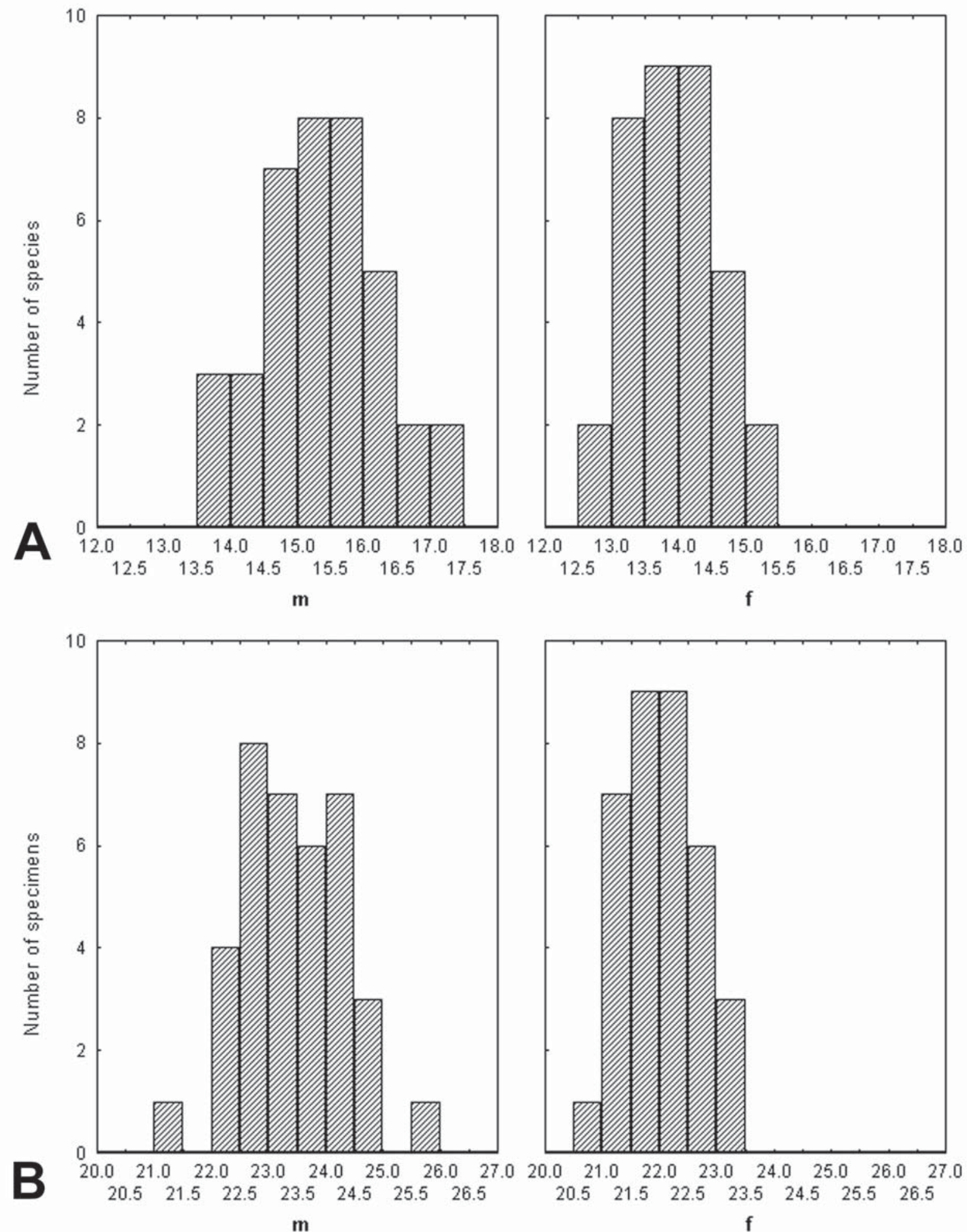

Figure 4. Frequency distribution of upper (A) and lower (B) carnassial teeth length (in mm) in males (m) and females (f) of $U$. arctos ferox. 

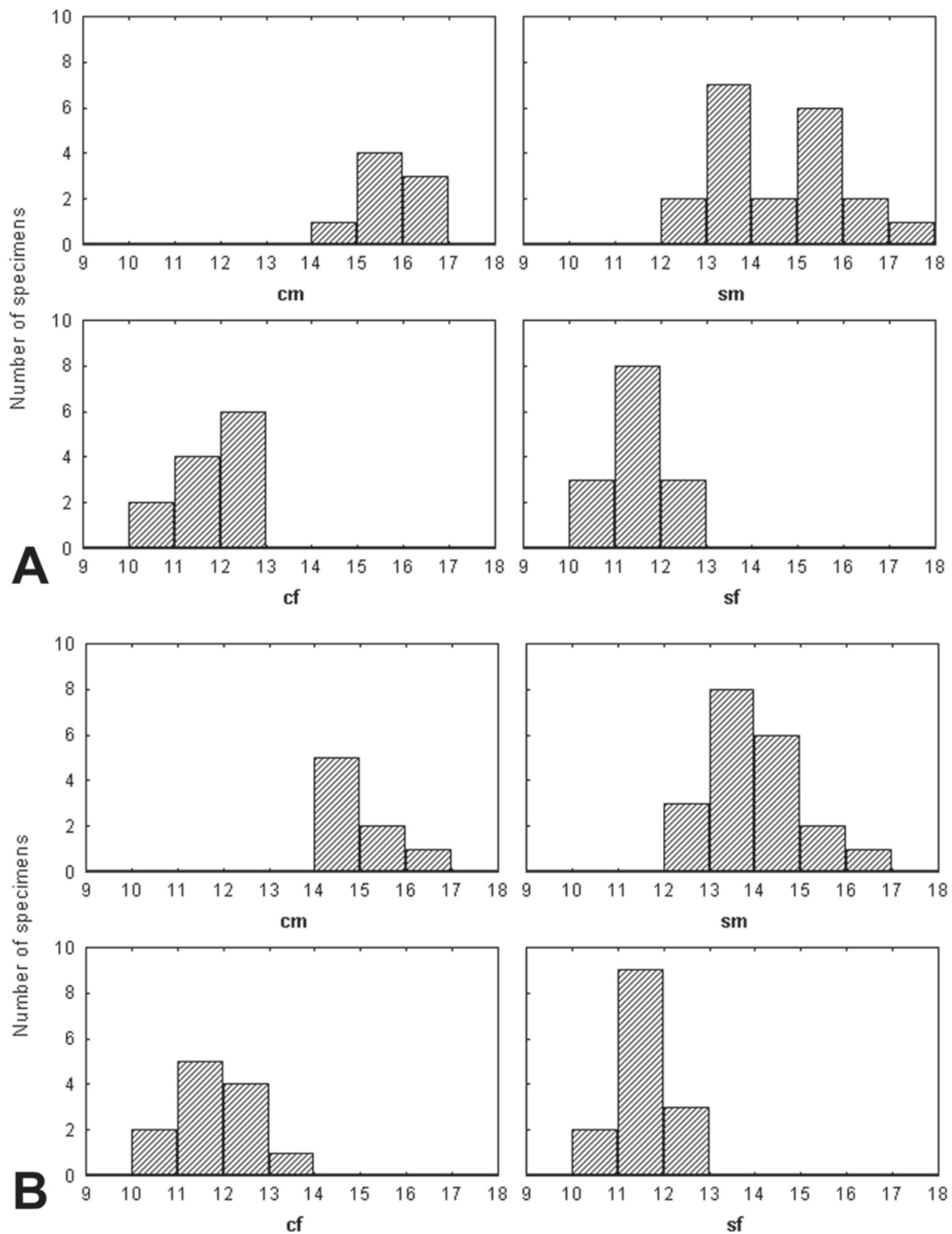

Figure 5. Frequency distribution of upper (A) and lower (B) canine width (in mm) in geographical groups of U. arctos ferox. $\mathrm{cf}$ - Central group, females; $\mathrm{cm}$ - Central group, males; $\mathrm{sf}$ - Southern group, females; sm — Southern group, males. 
Table 2. Male skull sizes in geographical groups of Ursus arctos ferox.

\begin{tabular}{|c|c|c|c|c|c|c|c|c|c|c|c|c|c|c|c|}
\hline \multirow{2}{*}{$\begin{array}{l}\text { Measurements, } \\
\mathrm{mm}\end{array}$} & \multicolumn{5}{|c|}{ Southern group } & \multicolumn{5}{|c|}{ Central group } & \multicolumn{5}{|c|}{ Eastern group } \\
\hline & $\mathrm{n}$ & $\min$ & $\max$ & M & SD & $\mathrm{n}$ & $\min$ & $\max$ & M & SD & $\mathrm{n}$ & $\min$ & $\max$ & M & SD \\
\hline 1 & 18 & 341.9 & 395.0 & 363.77 & 13.75 & 12 & 340.0 & 400.0 & 357.42 & 19.09 & 9 & 325.0 & 393.9 & 361.83 & 20.56 \\
\hline 2 & 18 & 310.1 & 382.0 & 334.23 & 17.23 & 11 & 320.0 & 367.0 & 342.78 & 16.50 & 9 & 315.0 & 366.5 & 342.65 & 14.79 \\
\hline 3 & 16 & 293.3 & 362.0 & 314.49 & 17.06 & 11 & 291.0 & 345.0 & 319.74 & 18.35 & 8 & 297.0 & 330.1 & 319.27 & 12.50 \\
\hline 4 & 18 & 193.5 & 226.0 & 206.54 & 9.07 & 12 & 186.7 & 236.3 & 207.54 & 14.93 & 9 & 185.1 & 224.5 & 203.64 & 12.85 \\
\hline 5 & 24 & 162.0 & 201.6 & 183.88 & 9.88 & 13 & 170.4 & 220.0 & 189.52 & 13.90 & 9 & 164.1 & 209.3 & 183.96 & 12.85 \\
\hline 6 & 24 & 122.2 & 158.7 & 137.99 & 8.36 & 12 & 126.6 & 158.8 & 140.36 & 9.66 & 9 & 123.6 & 156.1 & 138.80 & 8.94 \\
\hline 7 & 22 & 154.6 & 208.8 & 177.32 & 11.71 & 12 & 168.6 & 197.9 & 183.38 & 8.60 & 9 & 168.1 & 197.3 & 180.58 & 8.96 \\
\hline 8 & 24 & 112.4 & 138.9 & 126.95 & 7.13 & 13 & 118.4 & 137.1 & 127.91 & 6.01 & 9 & 118.3 & 134.9 & 126.69 & 5.02 \\
\hline 9 & 24 & 68.7 & 83.3 & 73.93 & 3.29 & 13 & 66.8 & 82.5 & 74.32 & 5.13 & 9 & 67.8 & 74.9 & 72.15 & 2.48 \\
\hline 10 & 21 & 169.8 & 256.6 & 210.29 & 20.37 & 13 & 175.3 & 253.6 & 214.31 & 22.94 & 9 & 184.2 & 248.6 & 213.14 & 20.85 \\
\hline 11 & 18 & 96.1 & 110.3 & 101.12 & 3.60 & 12 & 98.1 & 104.5 & 101.36 & 2.04 & 9 & 102.3 & 107.6 & 104.89 & 1.69 \\
\hline 12 & 20 & 69.2 & 85.4 & 75.22 & 3.99 & 12 & 66.3 & 83.2 & 74.46 & 4.51 & 8 & 73.5 & 82.0 & 77.85 & 2.91 \\
\hline 13 & 23 & 59.7 & 92.4 & 76.64 & 8.05 & 13 & 72.5 & 94.6 & 81.48 & 6.62 & 9 & 65.9 & 89.1 & 78.47 & 7.64 \\
\hline 14 & 16 & 64.4 & 76.6 & 70.95 & 3.19 & 11 & 67.3 & 75.9 & 72.43 & 2.85 & 8 & 68.3 & 78.7 & 73.17 & 3.22 \\
\hline 15 & 18 & 149.8 & 190.0 & 170.32 & 11.48 & 13 & 140.7 & 195.0 & 174.80 & 16.39 & 8 & 140.7 & 191.8 & 165.40 & 20.02 \\
\hline 16 & 21 & 40.3 & 54.7 & 46.94 & 3.65 & 11 & 44.1 & 55.3 & 48.15 & 3.18 & 9 & 44.6 & 51.1 & 47.67 & 2.13 \\
\hline 17 & 24 & 77.4 & 90.7 & 84.15 & 3.74 & 13 & 74.5 & 95.5 & 85.21 & 4.87 & 9 & 80.3 & 94.0 & 87.89 & 4.39 \\
\hline 18 & 24 & 67.6 & 91.6 & 77.99 & 6.33 & 13 & 72.9 & 89.3 & 80.35 & 4.11 & 9 & 75.6 & 87.8 & 81.14 & 4.83 \\
\hline 19 & 24 & 40.3 & 54.5 & 47.98 & 3.99 & 13 & 42.6 & 57.1 & 48.81 & 3.78 & 9 & 43.4 & 53.1 & 49.94 & 2.85 \\
\hline 20 & 16 & 96.9 & 124.4 & 103.31 & 7.13 & 11 & 95.9 & 116.3 & 104.72 & 6.99 & 8 & 94.1 & 111.9 & 102.6 & 6.76 \\
\hline 21 & 23 & 209.5 & 268.8 & 236.53 & 12.89 & 13 & 221.9 & 253.3 & 240.84 & 10.39 & 9 & 218.8 & 261.3 & 238.91 & 14.06 \\
\hline 22 & 23 & 209.7 & 276.5 & 239.52 & 13.69 & 13 & 225.1 & 256.5 & 243.55 & 9.31 & 8 & 217.9 & 259.1 & 239.95 & 13.76 \\
\hline 23 & 24 & 128.3 & 159.8 & 144.22 & 7.74 & 13 & 139.1 & 154.4 & 147.69 & 4.73 & 9 & 136.1 & 153.8 & 144.91 & 6.47 \\
\hline 24 & 24 & 75.9 & 98.5 & 81.87 & 4.40 & 13 & 74.9 & 89.3 & 82.11 & 4.05 & 9 & 67.7 & 84.3 & 79.67 & 5.35 \\
\hline 25 & 23 & 89.8 & 120.0 & 107.40 & 7.05 & 13 & 101.2 & 119.4 & 111.59 & 6.28 & 9 & 99.4 & 124.9 & 110.33 & 8.39 \\
\hline 26 & 24 & 37.7 & 62.0 & 44.86 & 4.80 & 13 & 41.0 & 52.1 & 45.81 & 3.57 & 8 & 41.3 & 53.7 & 47.24 & 4.74 \\
\hline 27 & 24 & 38.7 & 53.4 & 42.87 & 3.22 & 13 & 37.8 & 50.7 & 44.46 & 3.82 & 9 & 42.4 & 48.7 & 44.54 & 2.12 \\
\hline
\end{tabular}

Abbreviations see Table 1.

palatal breadth, and greatest mastoid breadth $(60 \%$ of skull variation). No difference has been recorded between Eastern and Southern groups. However, the Eastern female sample includes only two specimens, which reduces the reliability of the obtained results.

The males of Eastern group are characterized by the relatively smaller cheek teeth. It resulted from the ratio between the length of the upper tooth row P4-M2 and condylobasal length of skull. This ratio constitutes in the average $21.1 \%$ for males belonging to Eastern group, whereas it was calculated as $21.7 \%$ for males from Central group and $22.1 \%$ for males from Southern group. This variation in the cheek tooth size may be associated with the geographical differences in the diet of the brown bear from Hokkaido. Presumably, animals from Eastern group consume more salmon fish (genus Oncorhynchus) as well as marine garbage. This hypoth- esis is ascertained by the comparatively small size of cheek teeth in very large brown bears of Kamchatka, which predominantly consume fish (male tooth index is $20.4 \%, n=52$ ). On the contrary, the bears from Southern group are mainly herbivores and, as a result, possess enlarged masticatory surface of their cheek teeth.

The discriminant function analysis based on the cheek tooth dimensions revealed the reliable difference between three male geographical samples of the brown bear of Hokkaido. The Eastern group is most isolated $(\mathrm{P}<0.003)$, the difference between Southern and Central groups being less pronounced $(\mathrm{P}<0.018)$. However, Southern and Central female samples are more reliably segregated by the cheek tooth measurements $(\mathrm{P}<0.0007)$.

The average skull condilobasal length in the males of U. a. ferox $(339.16 \mathrm{~mm}, \mathrm{n}=41)$ is markedly lower than that in males from Amur River basin and Shantarskie Islands 


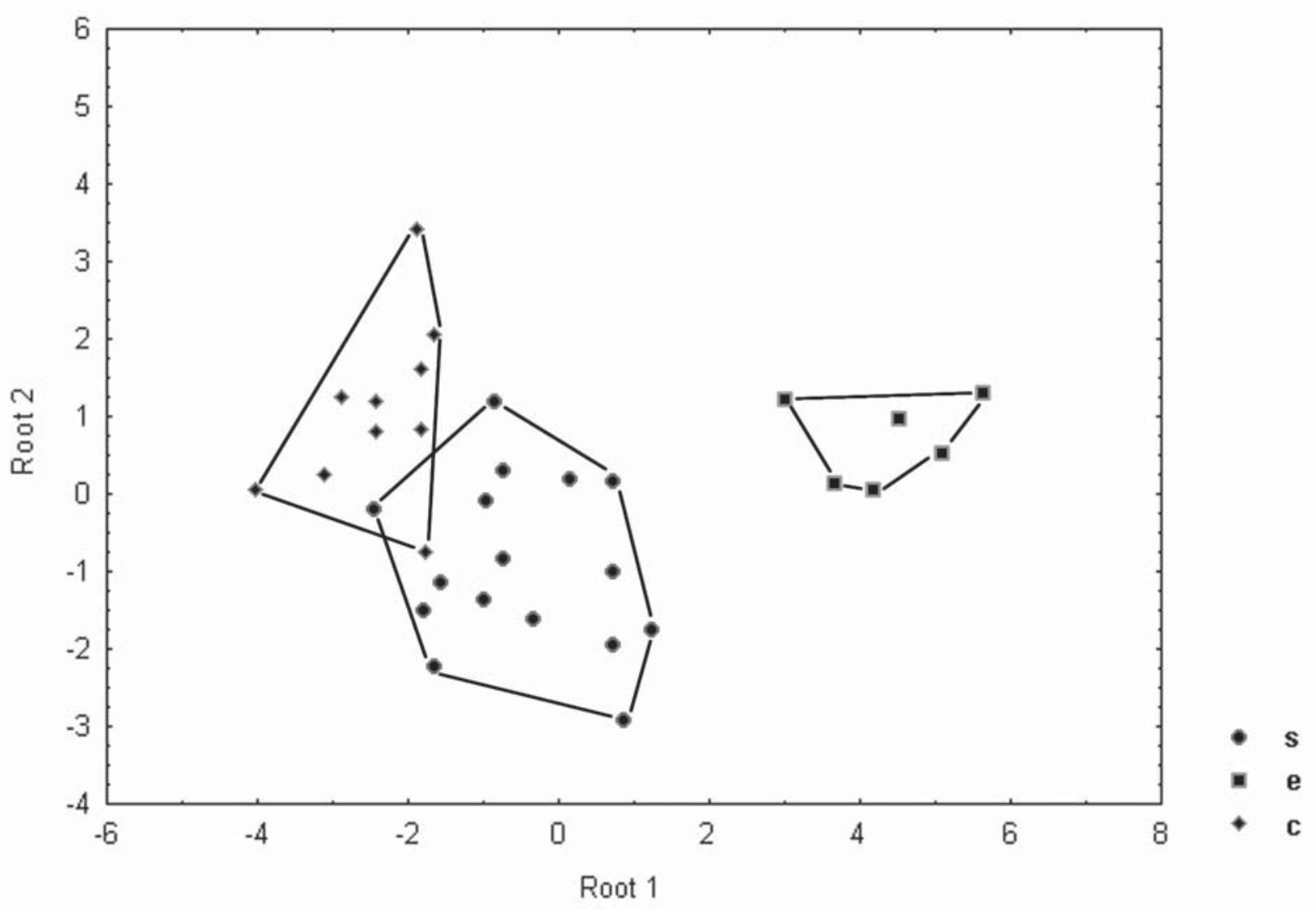

Figure 6. Plot of canonical scores for each geographical group on the plane canonical variates Root 1 and Root 2 for male skull of $U$. arctos ferox.

$\mathrm{c}$ - Central group, e - Eastern group, $\mathrm{s}$ - Southern group.

(377.72 $\mathrm{mm}, \mathrm{n}=14)$ as well as from Kamchatka $(370.88$ $\mathrm{mm}, \mathrm{n}=52)$. At the same time, this parameter is somewhat exceed that in the representatives of $U$. a. arctos from the European Russia (332.21 mm, $\mathrm{n}=24)$ and from Yakutia and Anadyr' River basin (329.60 mm, n=19).

The craniometrical comparison of the brown bears from Hokkaido and Sakhalin has demonstrated their clear heterogeneity in the skull size as well as in cheek tooth dimensions. In the males from Sakhalin, the average condylobasal length $(370.34 \mathrm{~mm}, \mathrm{n}=7)$ markedly exceeds that in the bears from Hokkaido. The ratio between the length of the upper tooth row P4-M2 and condylobasal length in Sakhalin bear $(20.5 \%)$ appeared to be similar to that in the brown bears from Kamchatka. At the same time, this index is markedly lower as compared to those calculated for geographical groups of U. a. ferox.

The cluster analysis based on 27 skull measurements of $U$. arctos from Eurasia united the samples examined into 3 clusters (Fig. 7). The first cluster comprises brown bears from Kamchatka (U. a. piscator) as well as from Amur River basin, Shantarskie Islands and Sakhalin ( $U$. a. beringianus). Another cluster incorporated brown bears from Northern Eurasia (U. a. arctos) and Southern Siberia (U. a. collaris); no pronounced difference was found between these subspecies. The analysis has also revealed remarkable similarity of the samples from European Russia and Northeastern Siberia that confirmed their assignment to the nominotypical subspecies. The third cluster included all the groups of the brown bear from Hokkaido (U. a. ferox). A level of differentiation of Eastern group and other two geographical groups from Hokkaido corresponds to that between populations of $U$. a. beringianus from the mainland and Sakhalin, while the level of differentiation between Central group and Southern group coincides with subspecific difference between $U$. a. arctos and $U$. $a$. collaris.

The second cluster analysis based on 30 tooth dimensions for the Eurasian samples of $U$. arctos provided a rather different result (Fig. 8). The subspecies $U$. $a$. piscator, which has the comparatively smallest teeth, occupies an isolated position. U. a. arctos (European Russia) and U. a. beringianus (Amur River basin and Shantarskie Islands) are united into a single cluster, whereas the subspecies $U$. a. ferox constituted ones more cluster. Hokkaido brown bears belonging to Eastern group were remote in the dendrogram from the bears of other two geographical groups on the same distance as subspecies $U$. a. beringianus and U. a. arctos. 


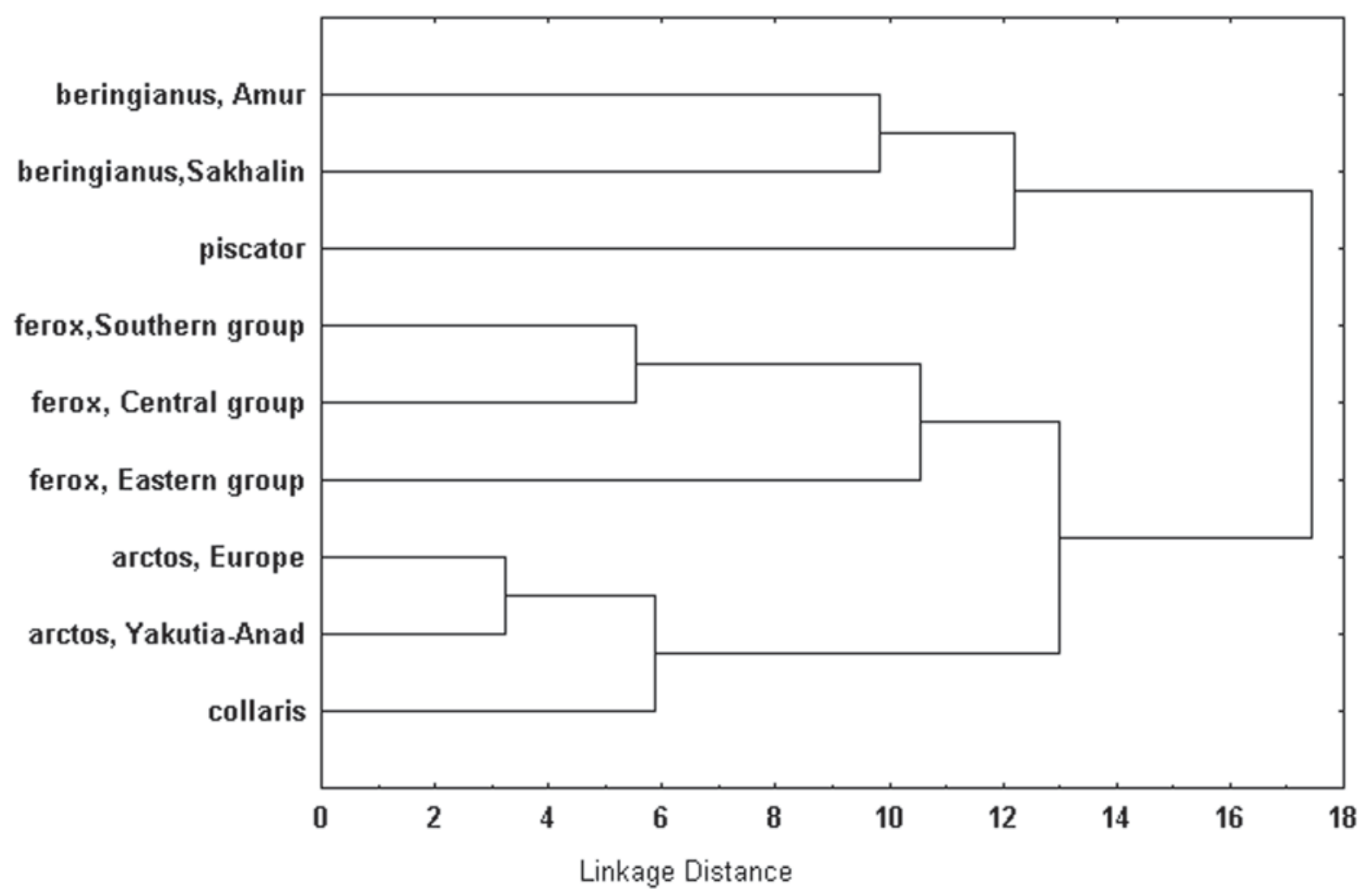

Figure 7. Hierarchical tree plot for male skulls of $U$. arctos ferox according to squared Mahalanobis distances.

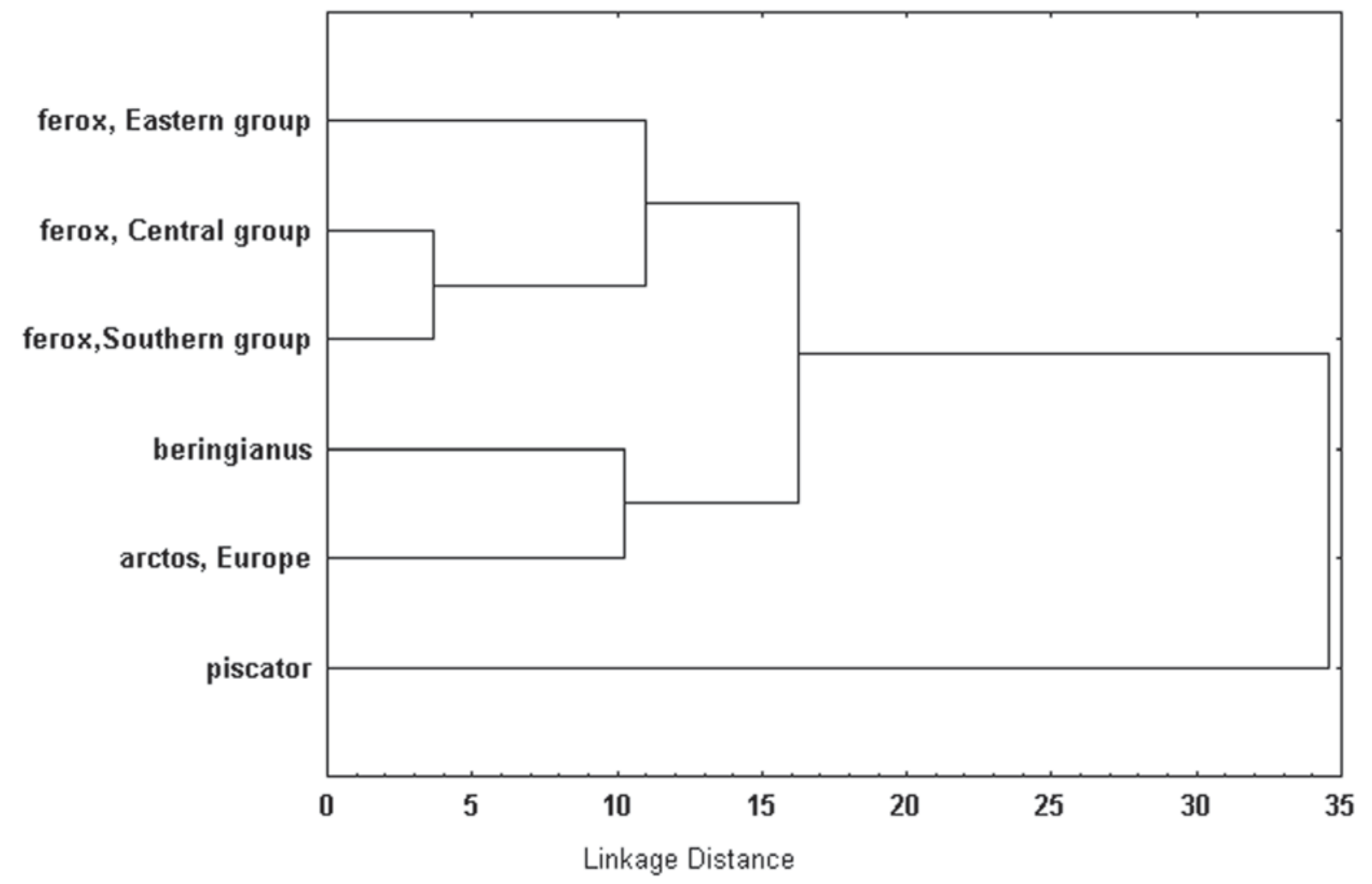

Figure 8. Hierarchical tree plot for male cheek teeth of U. arctos ferox according to squared Mahalanobis distances. 


\section{Discussion and conclusion}

The morphometrical test of the phylogeographical patterns of the modern population of Hokkaido brown bears based on mtDNA control region sequences (Matsuhashi et al., 1999) revealed the considerable isolation of the bears from Eastern group. The males belonging to Central group and Southern group appeared to be morphometrically similar; however, females of these groups demonstrated reliable distinction. Therefore the difference between geographically separated female samples is more pronounced than that between male samples. This phenomenon may be explained by the smaller size of the female home range with respect to that of the male home range in Hokkaido (Mano, 1994), thus females may more rarely mix with the adjacent populations.

It should be mentioned that the genetic evidence divided more distantly bears of Southern group (Cluster C) from other two groups (Matsuhashiet al., 1999). This discrepancy with the results of the present analysis suggests that the size and proportions of the skull and cheek teeth are determined in each group by the local adaptations: the bear diet, environmental conditions, and size of the population territories and their isolation. Southern group and Central group demonstrate more pronounced morphological similarity because of their representatives were subjected less adaptive selection than brown bears of Eastern group.

The bears of three genetic lineages of $U$. arctos might originate in the mainland and immigrate then to Hokkaido through Sakhalin using land bridges formed in the last glaciation, when the ocean level regressed (Matsuhashi et al., 1999). Judging from the pattern of their modern distribution, brown bears belonging to Southern and Eastern groups first immigrated to Hokkaido. Their followers from Central group forced out the bears of Southern and Eastern groups correspondingly to the southern and eastern peripheries of the island. The bears from Eastern group are established to have subspecific level of differentiation. In fact, mtDNA lineage of Eastern group is the same as that of eastern Alaskan brown bears (Matsuhashiet al., 2001). A morphological differentiation of Eastern group was supported by the genetic features.

Our study revealed that recent brown bears in Sakhalin are craniometrically well distinguished from the animals in Hokkaido. It may be a result of the rapid morphometrical modification of skull and dentition in the Hokkaido brown bears as well as the postglacial colonization of Sakhalin by new animals from Siberia. Notably, the brown bears, inhabiting Schmidt Peninsula located in the north extremity of Sakhalin, are smaller than bears from other parts of the island (Vshivtsev, 1972). In addition, the subfossil skull from Mishutkina Cave(ZIN 35281) in Eastern-Sakhalinskie Mountains is similar to the male skulls from Schmidt Peninsula in the condilobasal length $(354 \mathrm{~mm})$. These data suggest the wider former distribution of smaller bears in Sakhalin, with their later forcing out to the north of the island by larger mainland immigrants.
Fragmentary paleontological material available from the territory of Yakutia testifies occurrence there in the Middle and Late Pleistocene of U. arctos of the large and medium size (Baryshnikov \& Boeskorov, 1998). The formation of the extremely severe environmental conditions of the last glaciation resulted in the deterioration of forage reserve for brown bears had led to the appearance in the north of Siberia of smaller bears belonging to the nominotypical subspecies. Larger animals preserved in the regions, which are reach in the anadrom salmons (Kamchatka, Sakhalin) or characterizing in the abundant vegetation (Amur River basin). Notably, the largest and most broad-faced brown bears (U. a. piscator, U. a. middendorffi) confined to the Northern Pacific, exactly to the places spawning of the most robust species of the genusOncorhynchus (O. nerka, O. tschawytscha)(Cherniavsky \& Kretchmar, 2001).

Summarizing, our investigation testifies morphometrical distinction of the genetic lineages of Hokkaido brown bears established previously on the basis of sequencing of mtDNA. Our analysis indicated that the brown bears from Hokkaido and southern Kuril Islands belong to the subspecies $U$. arctos ferox, which is morphometrically well distinguished from other brown bear subspecies inhabiting the region of the Okhotsk Sea. The distribution of all the regional subspecies is shown in the Fig. 9.

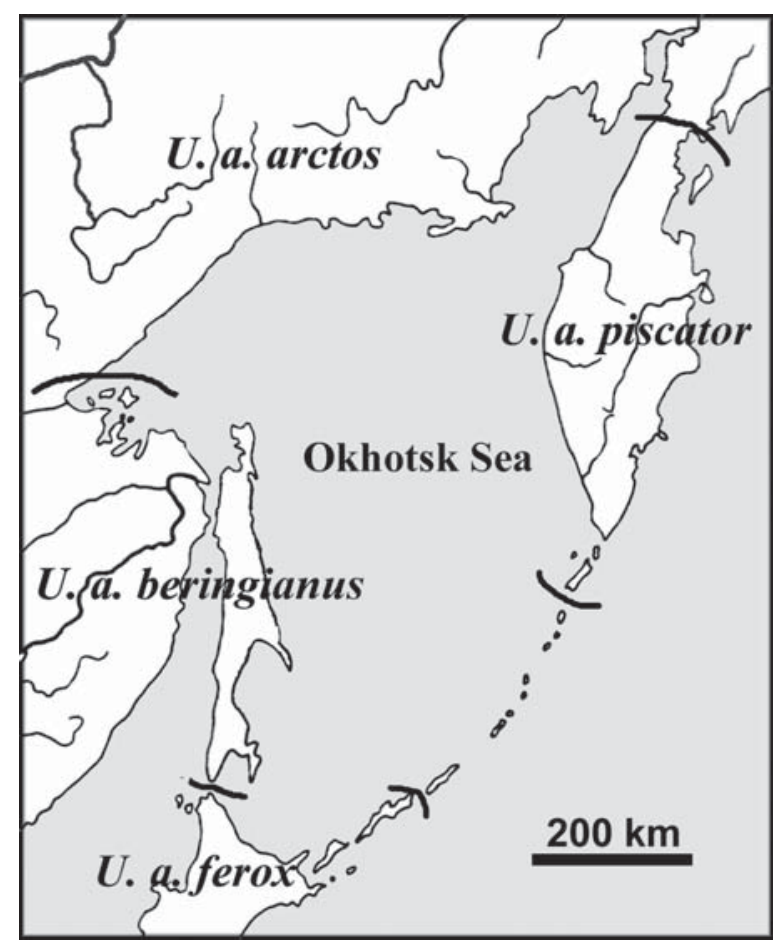

Figure 9. Distribution of subspecies ofUrsus arctos in Okhotsk Sea region.

ACKNOWLEDGEMENTS. We would like to thank Dr. H. Endo (NSMT), Dr. M. Murakami (FSCVB), Dr. I. Pavlinov (ZMMU) and Dr. P. Jenkins (NHM) for the permission to study collections. We are also grateful to Dr. K. Tsytsulina (Hokkaido Univ.) for her helpful assistance. The visit of Gennady Baryshnikov to Japan was funded by the 21 st 
Century COE Program "Neo-Science of Natural History" at Hokkaido University from the Ministry of Education, Culture, Sports, Science and Technology, Japan.

\section{References}

Abramov A.V. \& Baryshnikov G.F. 1990. [Catalog of Type Specimens in the Collection of Zoological Institute of Academy of Sciences of the USSR. Mammals (Mammalia). N 2. Carnivora, Proboscidea, Desmostylia]. Leningrad: Izdatel'stvo Zoologicheskogo Instituta AN SSSR. 24 p. [in Russian].

Aristov A.A. \& Baryshnikov G.F. 2001. [The Mammals of Russia and Adjacent Territories. Carnivores and Pinnipeds]. Santkt-Peterburg: Izdatel'stvo Zoologicheskogo Instituta RAN. 560 p. [in Russian].

Baryshnikov G.F. 1998. Cave bears from the Paleolithic of the Greater Caucasus // Saunders J.J., Styles B.W. \& Baryshnikov G.F. (eds.). Quaternary Paleozoology in the Northern Hemisphere. Springfield, Illinois State Museum Scientific Papers. Vol.27. P.69-118.

Baryshnikov G.F. \& Boeskorov G.F. 1998. [Brown bear Ursus arctos (Carnivora, Ursidae) from the Pleistocene of Yakutia] // Byulleten' Moskovskogo Obshchestva Ispytatelei Prirody, Otdel Biologicheskiy. T.103. No.2. P.3-9 [in Russian, with English summary].

Baryshnikov G.F. \& David F. 2000. Les ours des cavernes a Arcy-sur-Cure (Yonne, France) - Ursus (Spelearctos) spelaeus Rosenmüller et Heinroth, 1784 // Quaternaire. T.11. No.1. P.65-79.

Baryshnikov G.F. \& Germonpré M., Sablin M.V. 2003. Sexual dimorphism and morphometric variability of check teeth of the cave bear (Ursus spelaeus) // Belgian Journal of Zoology. T.133. No.2. P.111-119.

Cherniavsky F.B. 1984. [Mammals of North-East Siberia]. Moskva: Nauka. 389 p. [in Russian].

Cherniavsky F.B. 1986. [To the systematics and history of the brown bear (Ursus arctos) in the Beringian Sector of Subarctic] // Cherniavsky F.B. \& Chereshnev I.A. (eds.). [Biogeography of the Beringian Sector of Subarctic]. Vladivostok: Izdatel'stvo Dal'nevostochnogo Nauchnogo Tsentra AN SSSR. P.182-193 [in Russian].

Cherniavsky F.B. \& Kretchmar M.A. 2001. [Brown bear (Ursus arctos) in North-East of Siberia]. Magadan: Izdatel'stvo Instituta Biologicheskikh Problem Severa RAN. 93 p. [in Russian, with English summary].

Corbet G.B. 1978. The Mammals of the Palaearctic Region: A Taxonomic Review. London: British Museum (Natural History). 314 p.

Desmarest A.G. 1820. Mammalogie, ou description des espèces de mammifères. Prs. 1. Paris. 555 p.

Ellerman J.R. \& Morrison-Scott T.C.S. 1951. Checklist of Palaearctic and Indian Mammals 1758 to 1946. London: British Museum (Natural History). 810 p.

Gray J.E. 1867. Note on Ursus lasiotus, a hairy-eared bear from North China // Annals and Magazine of Natural History, Series 3. Vol.20. P.301.

Heptner V.G., Naumov N.P., Yurgenson P.B., Sludsky A.A., Chirkova A.F. \& Bannikov A.G. 1967. [The Mammals of Soviet Union. Vol.2. Pt.1. Sea Cows and Carnivores]. Moskva: Vysshaya Shkola. 1004 p. [in Russian].
Kamei T. 1981. Faunal succession of Pleistocene mammals in the Japanese islands: An aspect // Quartärpaläontologie. Bd.4. P.165-174.

Kurtén B. 1955. Sex dimorphism and size trends in the cave bear, Ursus spelaeus Rosenmüller and Heinroth // Acta Zoologica Fennica. Vol.90. P.1-48.

Lydekker R. 1897. The blue bear of Tibet, with notes on the members of the Ursus arctos group // Proceedings of the Zoological Society of London. P.412-426.

Mano T. 1994 Home range and habitat use of brown bears in the southwestern Oshima Peninsula, Hokkaido // International Conference of Bear Researchers and Managers. Vol.9. No.1. P.319-325.

Matsuhashi T., Masuda R., Mano T. \& Yoshida M.C. 1999. Microevolution of the mitochondrial DNA control region in the Japanese brown bear (Ursus arctos) population // Molecular Biology and Evolution. Vol.16. No.5. P.676-684.

Matsuhashi T., Masuda R., Mano T., Murata K. \& Aiurzaniin A. 2001. Phylogenetic relationships among worldwide populations of the brown bear Ursus arctos // Zoological Science. Vol.18. No.8. P.1137-1143.

Middendorff A. 1851. Untersuchungen an Schädeln des gemeinen Landbären, als kritische Beleuchtung der Streitfrage über die Arten fossiler Höhlenbären // Verhandlungen der Russisch-Kaiserlichen Mineralogieschen Gesellschaft zu St. Petersburg. Jg. 1850-1851. S.7-99.

Novikov G.A. 1956. [Carnivorous Mammals of the USSR Fauna]. Moskva-Leningrad: Izdatel'stvo Akademii Nauk SSSR. 295 p. [in Russian].

Ognev S.I. 1931. [Mammals from Eastern Europe and Northern Asia. T.2.] Moskva-Leningrad: Glavnoe Upravlenie Nauchnymi Uchrezhdeniyami, Gosudarstvennoe Izdatel'stvo. 776 p. [in Russian].

Ohdachi S., Aoi T., Mano T. \& Tsubota T. 1992. Growth, sexual dimorphism, and geographical variation of skull dimension of the brown bearUrsus arctos in Hokkaido // Journal of the Mammalian Society of Japan. Vol.17. No.1. P.27-47.

Pocock R. 1932. The black and brown bears of Europe and Asia // Journal of the Bombay Natural History Society. Vol.35. No.3. P.771-823.

Pucheran. 1855. Notes mammalogiques // Revue et magazine de Zoologie, Série 2. T.7. P.392-394.

Rafinesque C.S. 1817. Extracts from the journal of Mr. Charles Le Raye, relating to some new quadrupeds of the Missouri region, with notes by C. S. R. In: Rafinesque C.S. Museum of Natural Sciences // American Monthly Magazine. Critical Review, 1817. Vol.1. No.6. P.431-442.

Temminck C.J. 1842. Mammifères // Siebold Ph.F. (ed.). Fauna Japonica. Vol.2. Leiden. 26 p. +30 Tab.

Stroganov S.U. 1962. [Mammals of Siberia. Carnivores]. Moskva: Izdatel'stvo Akademii Nauk SSSR. 459 p. [in Russian].

Vshivtsev V.P. 1972. Some data on the brown bear of Sakhalin Province and adjacent territories // Sokolov V.E. (ed.). [Ecology, Morphology, Conservation, and Use of Bears]. Moskva: Nauka. P.29-32 [in Russian].

Yoneda M. \& Abe H. 1976. Sexual dimorphism and geographic variation in the skull of the Ezo brown bear (Ursus arctos yesonensis) // Memoirs of the Faculty of Agriculture, Hokkaido University. Vol.9. P.265-276 [in Japanese with English abstract]. 